\title{
Analisis Efektivitas Konsep Pengelolaan Sampah Organik melalui Teknologi Komposting (Studi Kasus di Kota Probolinggo, Jawa Timur)
}

\section{The Effectiveness Analysis of Organic Waste Management Concept Through Technology Composting (Case Study in Probolinggo City, East Java)}

\author{
Sri Wahyono \\ Pusat Teknologi Lingkungan - BPPT \\ Gedung Geostech 820, Puspiptek Serpong 15314, Indonesia \\ Email : sri.wahyono@bppt.go.id
}

Diterima : 16 November 2015; Diperiksa : 20 November 2015; Revisi : 07 Desember 2015; Disetujui :21 Desember 2015

\begin{abstract}
The aim of this study was to test the effectiveness of the concept of organic waste management through composting technology by the analysis of material flow. The scenario of organic waste management concept consists of four scenarios with involves of three scale of compostings such as household skala, neighbour scale, and city scale. Various scenarios were then analyzed the flow of material with material flow analysis (MFA) method which uses STAN software version 2.0.1703. The selected indicators in the analysis of material flow includes a material waste flow, Nitrogen $(\mathrm{N})$, Methane $\left(\mathrm{CH}_{4}\right)$, recyclable materials, compost, and residue. Assuming the entire organic waste is composted it will get the compost product of 11,222,817 kg/year, recyclable materials amounted to 8,897,809 kg/year (which consists of material of paper, plastic, metal and glass), $\mathrm{CH}_{4}$ gas reduction of 2,326,008 tons/year to be 9,255 $18,344 \mathrm{~kg} / \mathrm{year}$, and the conservation of $\mathrm{N}$ at $49,646 \mathrm{~kg} / \mathrm{year}$. Its concluded that the concept of waste management, especially decentralized composting is an effective alternative waste management because it is labor intensive; can adapt well to the socio-economic conditions of the region; creating jobs for unskilled people; management and operation is flexible so that it can quickly adapt to changes.
\end{abstract}

Keywords: Analysis of the flow of material, organic waste, composting

\begin{abstract}
ABSTRAK
Tujuan dari penelitian ini adalah menguji efektivitas konsep pengelolaan sampah organik melalui analisis aliran material. Konsep pengelolaan sampah organik yang dianalisis terdiri atas empat skenario yang melibatkan komposting skala rumah tangga, skala lingkungan dan skala kota. Berbagai skenario tersebut kemudian dianalisis aliran materialnya dengan metode analisis aliran material yang menggunakan software STAN versi 2.0.1703. Indikator yang dipilih dalam analisis aliran material meliputi aliran massa sampah, Nitrogen $(\mathrm{N})$, gas metana $\left(\mathrm{CH}_{4}\right)$, recyclable materials, kompos, dan residu. Dengan asumsi seluruh sampah organik dikomposkan maka akan didapatkan produk kompos sebesar 11.222.817 $\mathrm{kg} / \mathrm{tahun}$, recyclable materials sebesar $8.897 .809 \mathrm{~kg} / \mathrm{tahun}$ (yang terdiri atas material kertas, plastik, metal dan kaca), reduksi gas $\mathrm{CH}_{4}$ dari 2.326.008 ton/tahun hingga menjadi $9.255-18.344 \mathrm{~kg} / \mathrm{tahun}$, dan konservasi unsur $\mathrm{N}$ sebesar $49.646 \mathrm{~kg} / \mathrm{tahun}$. Konsep pengelolaan sampah, terutama desentralisasi komposting merupakan alternatif pengelolaan sampah yang efektif karena bersifat padat karya; dapat beradaptasi secara baik pada kondisi sosio-ekonomi daerah; menciptakan lapangan kerja bagi masyarakat berketerampilan terbatas; dan manajemen serta operasinya fleksibel sehingga secara cepat dapat beradaptasi dengan perubahan.
\end{abstract}

Kata kunci: Analisis aliran material, sampah organik, komposting

\section{PENDAHULUAN}

\subsection{Latar Belakang}

Konsep pengelolaan sampah organik melalui teknologi komposting merupakan konsep pengelolaan sampah organik menjadi kompos yang mempertimbangkan sistem desentralisasi dan sentralisasi komposting; pendekatan wilayah internal perkotaan sebagai basis analisis supplydemand kompos; aplikasi teknologi komposting yang terseleksi; dan elemen-elemen pengelolaan sampah. Jika tidak mempertimbangkan sistem desentralisasi atau sentralisasi komposting akan menghasilkan keputusan yang keliru yang akan berujung pada kegagalan kegiatan komposting sampah kota. Menurut penelitian sebelumnya, 
dengan studi kasus yang sama yaitu di Kota Probolinggo, sistem yang cocok untuk tipologi kota sedang adalah sistem desentralisasi komposting $^{(1)}$.

Pendekatan wilayah internal perkotaan sebagai basis analisis supply-demand kompos juga dijadikan dasar konsep pengelolaan sampah organik karena di wilayah internal perkotaan sesungguhnya memiliki sejumlah konsumen kompos potensial yang dapat menyerap produksi kompos dari sampah kota. Konsumen potensial, dengan kasus Kota Probolinggo, telah dipetakan namun belum dibangun menjadi konsumen nyata. Di Kota Probolinggo, potensi demand jauh lebih tinggi dari potensi supply sehingga secara teoritis pemasaran kompos tidak perlu lagi dilakukan ke luar wilayah kota ${ }^{(2)}$. Jika produk kompos didorong untuk dipakai di wilayah internal kota, maka pengelolaan sampah perkotaan akan berjalan berkelanjutan, sekaligus menciptakan siklus unsur hara tanah di ekosistem perkotaaan.

Selain itu, konsep pengelolaan sampah organik juga mempertimbangkan jenis teknologi komposting yang diaplikasikan. Jenis teknologi yang dipilih akan sangat berpengaruh pada efisiensi dan efektivitas aliran input materi sampah, energi dan air dan aliran output kompos, recyclable materials, residu sampah dan emisi gas. Pemilihan teknologi komposting membantu mengatasi masalah ketidaklayakan teknologi komposting yang merupakan salah satu penyebab kegagalan komposting. Teknologi komposting yang digunakan dalam penelitian ini merupakan teknologi terseleksi hasil analisis mutikriteria yang telah dilakukan secara komprehensif. Teknologi tersebut adalah teknologi komposting sistem windrow skala lingkungan dan skala kota dan teknologi komposter 'Aerobik'(3).

Konsep pengelolaan sampah organik juga mempertimbangkan elemen-elemen pengelolaan sampah yang meliputi subsistem pengelolaan sampah yang meliputi pewadahan, pengumpulan, pengangkutan, pengolahan dan pembuangan sampah di TPA yang menjadi ruang lingkup dalam analisis material dalam penelitian ini.

\subsection{Tujuan}

Tujuan dari penelitian ini adalah menguji efektivitas konsep pengelolaan sampah organik melalui analisis aliran material.

\section{BAHAN DAN METODE}

Konsep pengelolaan sampah organik disusun dalam empat skenario. Pada Skenario 1, seluruh sampah organik $(100 \%)$ diolah melalui komposting skala lingkungan. Sementara itu, pada Skenario 2, sebanyak 30\% sampah yang dihasilkan oleh perumahan diolah di rumah tangga dan sisanya beserta seluruh sampah dari sumber lainnya diolah di beberapa plant komposting skala lingkungan. Pada Skenario 3, seluruh sampah dari berbagai sumber diangkut dan diolah di sebuah plant komposting yang tersentralkan. Selanjutnya pada Skenario 4, sebanyak $30 \%$ sampah dari pemukiman diolah di rumah tangga, sedangkan selebihnya dan sampah dari sumber-sumber lainnya diolah di sebuah plant komposting skala kota.

Skenario tersebut dianalisis aliran materialnya dengan metode analisis aliran material (Material Flow Analysis/MFA) yang menggunakan software STAN versi 2.0.1703. Indikator yang dipilih dalam analisis aliran material meliputi aliran massa sampah, substansi Nitrogen (N) sebagai komponen penting dalam kompos, dan gas metana $\left(\mathrm{CH}_{4}\right)$. Sistem dibatasi pada pengelolaan sampah di Kota Probolinggo yang meliputi beberapa elemen proses yaitu: pengumpulan, Tempat penampungan sementara sampah (TPS), pengangkutan, tempat pemrosesan akhir (TPA), komposting skala rumah tangga, komposting skala lingkungan, dan komposting skala kota. Input material sampah meliputi sampah yang berasal dari berbagai sumber seperti perumahan, pasar, pertamanan, industri, pertokoan dan jasa, dan sebagainya. Material antar proses meliputi residu sampah yang dibuang ke TPA dan sampah yang diolah di tempat komposting. Output material meliputi gas $\left(\mathrm{CH}_{4}\right)$, recyclable materials dan kompos.

\section{HASIL DAN PEMBAHASAN}

\subsection{Base Line Aliran Material}

Dalam pengelolaan sampah tanpa intervensi pengolahan, sampah dari berbagai sumber dikumpulkan dan diangkut ke TPS. Dari TPS, sampah kemudian diangkut dan ditimbun di TPA. Dalam pengelolaan tersebut, material sampah yang ditimbulkan berakhir di TPA. Sampah tidak termanfaatkan dan menjadi sumber pencemaran lingkungan perkotaan.

Dalam Pedoman IPCC untuk Inventori Gas Rumah Kaca Nasional disebutkan bahwa sektor limbah (waste) adalah salah satu sektor yang menghasilkan gas rumah kaca ${ }^{(4)}$. Gas $\mathrm{CH}_{4}$ yang diproduksi oleh sektor persampahan secara global menyumbangkan sekitar 3 sampai 4 persen emisi gas rumah kaca antropogenik dunia. Di tingkat nasional, dari 17 TPA yang tersebar di kota-kota besar di Indonesia seperti Jakarta, Semarang, Jogjakarta, Semarang, Surabaya, dan Medan, gas $\mathrm{CH}_{4}$ yang diproduksinya diperkirakan sekitar 404 juta 
$\mathrm{m}^{3} / \operatorname{tahun}^{(5)}$. Sementara itu, berdasarkan perhitungan dari Tim TNA Indonesia, prediksi total rata-rata emisi gas rumah kaca dari tahun 2000 sampai 2005 di seluruh Indonesia adalah $578 \mathrm{Gg} /$ tahun. Jika kondisinya tidak mengalami perubahan, maka emisi akan meningkat menjadi $588 \mathrm{Gg}$ pada tahun 2010, $594 \mathrm{Gg}$ pada tahun 2015, dan $600 \mathrm{Gg}$ pada tahun $2020^{(6)}$. Jumlah tersebut adalah jumlah yang besar dan harus dikendalikan.

Dari hasil penghitungan di Kota Probolinggo, jika sampah tidak diolah maka timbulan sampah yang dibuang ke TPA berjumlah $46.245 .500 \mathrm{~kg}$ setiap tahunnya. Dengan jumlah sampah tersebut, produksi emisi $\mathrm{CH}_{4}$ dari TPA diperkirakan $2.326 .008 \mathrm{~kg} / \mathrm{tahun}$. Data tersebut menjadi base line (data dasar) bagi pengembangan konsep pengelolaan sampah organik di wilayah internal kota. Data dasar aliran material sampah Kota Probolinggo dapat dilihat pada Gambar 1.

Dengan total timbulan sampah 46.245 .500 $\mathrm{kg} / \mathrm{tahun}$, diperkirakan komposisi recyclable materials yang laku untuk dijual sebanyak 8.897.809 kg/tahun dan residu sampah yang dibuang ke TPA sebanyak $2.815 .947 \mathrm{~kg} / \mathrm{tahun}$. Kemudian dari timbulan sampah organik, dengan jumlah dan komposisi yang berbeda-beda dari setiap sumber, diperkirakan jumlah kompos yang dapat diproduksi sebesar 11.222.817 kg/tahun. Hal tersebut dapat dilah pada Gambar 1 dan Tabel 1.

Tabel 1. Rincian proyeksi produksi kompos

\begin{tabular}{|c|c|c|c|}
\hline $\begin{array}{l}\text { Sumber } \\
\text { Sampah }\end{array}$ & $\begin{array}{l}\text { Timbulan } \\
\text { Sampah }^{\mathrm{a}} \\
\text { (kg/tahun) }\end{array}$ & $\begin{array}{c}\text { Komposisi } \\
\text { Sampah } \\
\text { Organik }^{\text {Or }} \\
(\%)\end{array}$ & $\begin{array}{c}\text { Proyeksi } \\
\text { Kompos }^{c} \\
\text { (kg/tahun) }\end{array}$ \\
\hline Perumahan & 33.766 .964 & 73,64 & 8.081 .448 \\
\hline Pasar & 8.781 .541 & 85,20 & 2.431 .609 \\
\hline Pertokoan & 1.355 .974 & 27,20 & 119.868 \\
\hline Kesehatan & 212.167 & 31,70 & 21.859 \\
\hline Industri & 411.478 & 49,13 & 65.702 \\
\hline Pertamanan & 1.717 .373 & 90,00 & 502.332 \\
\hline Jumlah & 46.245 .500 & & 11.222 .817 \\
\hline
\end{tabular}

Keterangan:

${ }^{a}$ dari analisis data BLH Kota Probolinggo ${ }^{(7)}$

${ }^{b}$ dari BLH Kota Probolinggo ${ }^{(7)}$

c Produksi kompos = laju produksi sampah $\mathrm{x}$ komposisi $\mathrm{x}$ transfer koefisien kompos

Dari analisis aliran material terlihat bahwa tanpa adanya upaya pengolahan, sampah terbuang dan tidak termanfaatkan. Padahal sampah adalah sumberdaya yang dapat dimanfaatkan kembali menjadi material berguna (seperti kompos dan recyclable materials). Tanpa pengolahan sampah, pada akhirnya sampah yang ditimbun di TPA akan menghasilkan lindi dan emisi $\mathrm{CH}_{4}$ yang berpotensi mencemari lingkungan.
Selain itu, tanpa adanya upaya pengolahan sampah, TPA yang digunakan akan cepat terisi penuh. Jika sudah penuh maka harus dicarikan TPA penggantinya. Padahal untuk mencari lokasi TPA yang baru relatif sulit karena keterbatasan llahan di kota dan penolakan masyarakat terhadap keberadaan TPA. Upaya pengolahan sampah akan mengurangi jumlah sampah yang dibuang ke TPA sehingga umur TPA dapat lebih lama.

\subsection{Analisis Aliran Material Sampah Melalui Aplikasi Teknologi Komposting}

Seperti disampaikan sebelumnya, dengan asumsi seluruh sampah organik dikomposkan maka akan didapatkan produk kompos sebesar $11.222 .817 \mathrm{~kg} / \mathrm{tahun}$. Komposting sampah kota memungkinkan material organik yang terkandung dalam sampah dikembalikan lagi ke tanah sehingga tingkat kesuburan tanah terjaga karena adanya tambahan material organik sebagai pengganti material yang terserap oleh tanaman yang dibudidayakan. Pengembalikan material organik ke alam berarti menjaga siklus alamiahnya. Dengan asumsi seluruh sampah dipilah maka proses pemilahan sampah yang dilakukan sebelum proses komposting akan menghasilkan recyclable materials sebesar $8.897 .809 \mathrm{~kg} /$ tahun yang terdiri atas material kertas, plastik, metal dan kaca. Yang dapat digunakan kembali menjadi bahan baku industri.

$\mathrm{Hal}$ itu dapat dapat mengefisienkan penggunaan bahan baku yang dieksploitasi dari alam seperti eksploitasi kayu untuk bahan baku kertas, eksploitasi minyak bumi untuk bahan baku plastik, ekploitasi bijih logam dan kaca.

Pengolahan sampah melalui komposting akan mereduksi gas $\mathrm{CH}_{4}$. Tanpa adanya pengolahan, material organik di TPA akan menghasilkan $\mathrm{CH}_{4}$ sebesar 2.326.008 ton/tahun, sedangkan jika diolah maka gas $\mathrm{CH}_{4}$ secara signifikan dapat diturunkan menjadi 9.255 -18.344 kg/tahun.

Proses komposting mampu mereduksi produksi $\mathrm{CH}_{4}$ karena prosesnya berlangsung aerobik sehingga yang terproduksi secara dominan adalah gas $\mathrm{CO}_{2}$. Gas tersebut tidak dianggap berkontribusi dalam pemanasan global karena masuk dalam material biogenik.

Reduksi gas $\mathrm{CH}_{4}$ melalui kegiatan komposting merupakan upaya pencegahan produksi gas metana. Pengalaman Indonesia mereduksi gas $\mathrm{CH}_{4}$ dari aplikasi komposting telah didapat melalui Program Subsidi Kompos dari World Bank pada tahun 2004-2005 di 16 kota di bagian barat wilayah Pulau Jawa yang telah berhasil mereduksi produksi gas $\mathrm{CH}_{4}$ sebanyak 11.049 $14.916 \mathrm{~m}^{3}$ atau setara dengan 254.129 343.074 ton $\mathrm{CO}_{2}^{(8)}$. 


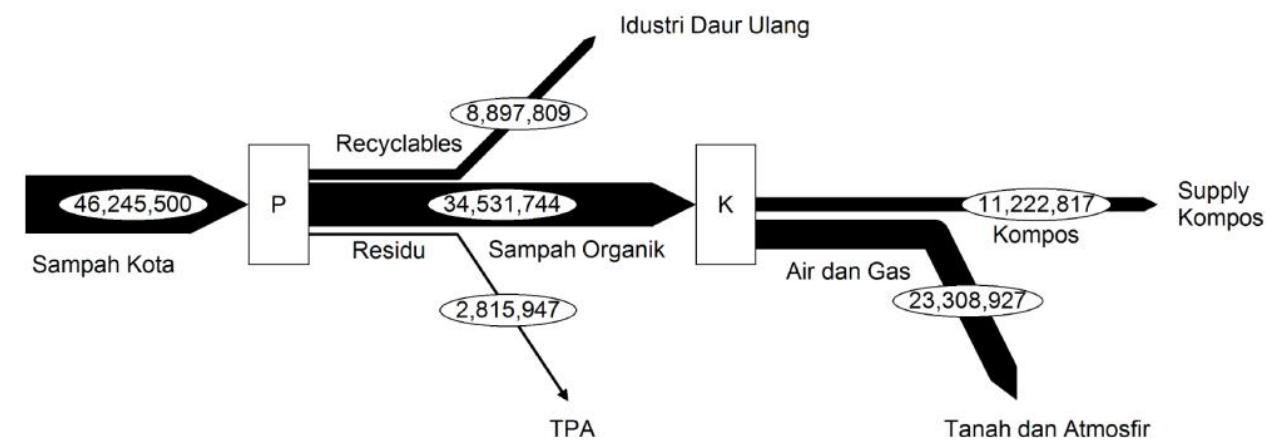

Gambar 1. Diagram aliran material sampah dan proyeksi timbulan kompos kota probolinggo

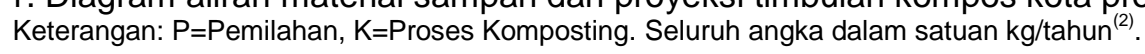

Tabel 2. Perbandingan input dan output material dari kegiatan komposting dan TPA

\begin{tabular}{l|c|c|c|c|c|c}
\hline \multirow{2}{*}{ Skenario } & \multicolumn{2}{|c|}{ Input } & \multicolumn{4}{c}{ Output } \\
\cline { 2 - 7 } & $\begin{array}{c}\text { Sampah } \\
\text { (kg/tahun) }\end{array}$ & $\begin{array}{c}\text { Air } \\
\text { (kg/tahun) }\end{array}$ & $\begin{array}{c}\text { Kompos } \\
\text { (kg/tahun) }\end{array}$ & $\begin{array}{c}\text { Recyclable } \\
\text { materials } \\
\text { (kg/tahun) }\end{array}$ & $\begin{array}{c}\text { Residu } \\
\text { (kg/tahun) }\end{array}$ & $\begin{array}{c}\text { Gas CH4 } \\
\text { (kg/tahun) }\end{array}$ \\
\hline Base Line (Ditimbun di TPA) & 46.245 .500 & - & 0 & 0 & 0 & 2.326 .008 \\
\hline $\begin{array}{l}\text { Desentralisasi/ Sentralisasi } \\
\text { Komposting }\end{array}$ & 46.245 .500 & $\begin{array}{c}5.334 .765 \\
\text { sampai } \\
6.804 .784\end{array}$ & 11.222 .817 & 8.897 .809 & 4.274 .913 & $\begin{array}{c}9.255 \\
\text { sampai } \\
18.344\end{array}$ \\
\hline
\end{tabular}

Komposting bermanfaat dalam konservasi unsur $\mathrm{N}$ dari material organik yang bermanfaat untuk memperbaiki kesuburan tanah. Unsur $\mathrm{N}$ yang dapat dikonservasi diprediksikan sebesar $49.646 \mathrm{~kg} / \mathrm{tahun}$. Sementara itu, jika sampah ditimbun di TPA, unsur $\mathrm{N}$ tidak termanfaatkan. Sebagian besar berada di badan sampah, dan sebagian lainnya terlarut dalam lindi dan diemisikan menjadi senyawa gas. Namun, dalam komposting juga secara alamiah unsur $\mathrm{N}$ sebagian besar diemisikan yaitu sebanyak $397.115 \mathrm{~kg} / \mathrm{tahun}$.

\subsection{Skenario 1}

Skenario 1 merupakan aplikasi sistem desentralisasi komposting dengan strategi mengolah seluruh sampah organik menjadi kompos melalui penerapan komposting skala lingkungan, tanpa melibatkan peranan komposting skala rumah tangga. Sampah yang ditimbulkan oleh setiap sumber sampah diasumsikan dikumpulkan untuk diolah di beberapa plant komposting skala lingkungan yakni berjumlah sekitar 46 ton/tahun atau $46.245 .500 \mathrm{~kg} /$ tahun, dengan sumber sampah terbesar berasal dari perumahan (berjumlah $33.766 .964 \mathrm{~kg})$ dan pasar $(8.781 .542 \mathrm{~kg})$.

Jumlah air yang diperlukan untuk penyiraman dalam proses komposting sekitar $67 \mathrm{~kg} / \mathrm{m}^{3}$ sampah. Dari hasil perhitungan didapatkan bahwa kebutuhan air total untuk proses komposting skala lingkungan adalah 6.804 .785 $\mathrm{kg} /$ tahun atau 6.805 ton/tahun.

Berdasarkan literatur, produksi gas metana dari proses komposting skala lingkungan sekitar
0,243-0,293 kg/ton sampah organik $^{(9)}$. Dari perhitungan didapatkan bahwa produksi gas metana dari seluruh proses komposting skala lingkungan adalah $9.255 \mathrm{~kg} / \mathrm{tahun}$.

Mengenai produksi kompos, dari material sampah organik sebanyak 1 ton dihasilkan kompos sebanyak $300-350 \mathrm{~kg}$, dengan berat jenis sekitar 0,5. Dari perhitungan didapat bahwa dari timbulan sampah kota sebanyak 46.245 .500 $\mathrm{kg}$ yang mengandung sampah organik $74,67 \%$ $(34.531 .743 \mathrm{~kg})$ dihasilkan kompos sekitar 11.223 ton atau $11.222 .817 \mathrm{~kg} /$ tahun.

Selain mendapatkan produk kompos, komposting skala lingkungan yang tersebar di berbagai lokasi juga me-recovery materialmaterial yang dapat di daur ulang (recyclable materials). Material yang berpotensi untuk di daur ulang adalah sampah kertas, plastik, metal dan kaca yang komposisinya secara berturut-turut sebesar 9,21\%; 8,20\%; 0,96\%; dan 0,87\%. Dari perhitungan diketahui bahwa jumlahnya diperkirakan mencapai $8.897 .809 \mathrm{~kg} / \mathrm{tahun}$. Recyclable materials tersebut merupakan bahan baku pada industri daur ulang.

Selain produk kompos, gas metana, dan recyclable materials, proses pemilahan pada komposting skala lingkungan menghasilkan sampah residu seperti sampah kayu, kain, karet/kulit, pasir dan jenis sampah lainnya, yang komposisinya berkisar antara $0,51 \%$ hingga $1,71 \%$. Dari perhitungan didapatkan bahwa laju timbulan residu diperkirakan sebanyak 4.274.913 $\mathrm{kg} /$ tahun. Residu tersebut kemudian diangkut dan ditimbun di TPA. 
Kandungan total unsur $\mathrm{N}$ di dalam sampah Kota Probolinggo diperkirakan $871.728 \mathrm{~kg}$. Hal tersebut didapat dari hasil perhitungan bahwa di dalam sampah mengandung $N$ sekitar 1,2-4\% dari total padatannya ${ }^{(10)}$. Sementara itu, kelembapan sampah itu sendiri berkisar antara $15-40 \%$, tergantung musim ${ }^{(11)}$.

Pada saat dikomposkan, unsur $\mathrm{N}$ sebagian berada dalam senyawa gas, senyawa lindi dan senyawa kompos. Sebagian besar unsur N berada di dalam gas yang diproduksi pada saat pengkomposan yaitu sebesar $397.115 \mathrm{~kg} / \mathrm{tahun}$. Hal itu didapat dari perhitungan bahwa di dalam gas yang diemisikan komposting skala lingkungan mengandung gas $\mathrm{N}_{2} \mathrm{O}-\mathrm{N}$ sekitar $1,115 \%$ berat basah sampah yang sedang dikomposkan ${ }^{(12)}$. Jumlah $\mathrm{N}$ yang dilepas ke udara tersebut relatif besar yang kemudian akan masuk siklus $\mathrm{N}$ secara alamiah di alam.

Unsur $\mathrm{N}$ yang berada di dalam kompos diperkirakan sebesar $49.646 \mathrm{~kg} /$ tahun. Hal itu didapat dari perhitungan bahwa di dalam kompos yang dihasilkan oleh Kota Probolinggo mengandung $0,58 \% \mathrm{~N}$ per berat kering kompos, di mana kelembapan komposnya adalah $23,73 \%$. Secara teoritis, unsur $\mathrm{N}$ juga dikandung oleh lindi. Namun jumlah lindi yang keluar dari proses komposting skala lingkungan relatif kecil sehingga dianggap tidak ada.

\subsection{Skenario 2}

Skenario 2 juga merupakan aplikasi sistem desentralisasi komposting seperti Skenario 1, tetapi dalam skenario tersebut disamping diasumsikan menerapkan komposting skala lingkungan, juga menerapkan komposting skala rumah tangga. Dalam komposting skala rumah tangga diskenariokan $30 \%$ sampah perumahan terolah, yaitu berjumlah $10.130 .089 \mathrm{~kg} / \mathrm{tahun}$. Sementara itu, sampah perumahan lainnya $(70 \%)$ dan sampah dari sumber lain diolah bersama-sama dalam beberapa plant komposting skala lingkungan. Jumlah sampah yang diolah melalui komposting skala lingkungan yaitu $36.115 .411 \mathrm{~kg} / \mathrm{tahun}$.

Dari hasil perhitungan didapatkan bahwa produksi gas metananya adalah $7.255 \mathrm{~kg} / \mathrm{tahun}$, sedangkan kompos yang dihasilkan sebanyak $8.798 .383 \mathrm{~kg} /$ tahun. Dari perhitungan diketahui pula bahwa laju produksi recyclable materials diperkirakan mencapai 6.813.037 kg/tahun, sedangkan laju timbulan residu diperkirakan sebanyak $3.374 .217 \mathrm{~kg}$.

Produksi gas metana dari proses komposting dalam komposter diperkirakan sekitar 0,788$2,185 \mathrm{~kg} /$ ton sampah organik ${ }^{(9)}$. Dari perhitungan didapatkan bahwa produksi gas metana dari seluruh proses komposting skala rumah tangga adalah $11.089 \mathrm{~kg} /$ tahun. Dari perhitungan didapatkan pula bahwa dari sampah organik yang dikomposkan di tingkat rumah tangga $(7.459 .797 \mathrm{~kg})$ dihasilkan kompos sebanyak 2.704.177 kg/tahun. Menurut Andersen, dari 1 ton sampah organik, dengan komposter individual, dihasilkan kompos sebanyak 272-453 $\mathrm{kg}$, dengan berat jenis sekitar $0,5^{(12)}$. Dari perhitungan diketahui pula bahwa jumlah recyclable materials dan residu diperkirakan mencapai $2.084 .772 \mathrm{~kg} / \mathrm{tahun}$ dan 900.696 $\mathrm{kg} /$ tahun.

Di dalam gas yang diemisikan komposting baik dari komposter skala rumah tangga maupun skala lingkungan mengandung $\mathrm{N}_{2} \mathrm{O}-\mathrm{N}$ sekitar $1,115 \%$ berat basah sampah yang sedang dikomposkan ${ }^{(12)}$. Dari perhitungan didapat bahwa unsur $\mathrm{N}$ yang yang diproduksi pada saat pengkomposan skala rumah tangga dan skala lingkungan yaitu sebesar $85.788 \mathrm{~kg} / \mathrm{tahun}$ dan $311.327 \mathrm{~kg} /$ tahun.

Unsur $\mathrm{N}$ yang berada di dalam kompos yang diproduksi dalam skala rumah tangga dan skala lingkungan diperkirakan sebesar $10.725 \mathrm{~kg} /$ tahun dan $39.921 \mathrm{~kg} /$ tahun. Secara teoritis, unsur $\mathrm{N}$ juga dikandung oleh lindi. Namun jumlah lindi yang keluar dari proses komposting relatif kecil sehingga dianggap tidak ada.

\subsection{Skenario 3}

Lain halnya dengan Skenario 1 dan 2, Skenario 3 merupakan aplikasi sistem sentralisasi komposting dengan strategi mengolah seluruh sampah organik menjadi kompos melalui penerapan komposting skala kota.

Dari perhitungan didapatkan bahwa produksi gas metana, kompos, recyclable materials dan residu dari seluruh proses komposting skala kota sama dengan komposting skala lingkungan yaitu secara berturut-turut $9.255 \mathrm{~kg} /$ tahun, 11.222 .817 $\mathrm{kg} /$ tahun, $8.897 .809 \mathrm{~kg} / \mathrm{tahun}$, dan 4.274 .913 $\mathrm{kg} /$ tahun.

Telah diketahui bahwa kandungan total unsur $\mathrm{N}$ di dalam sampah Kota Probolinggo diperkirakan $871.728 \mathrm{~kg}$. Sebagian besar unsur $\mathrm{N}$ berada di dalam gas yang diproduksi pada saat pengkomposan yaitu sebesar 397.115 $\mathrm{kg} /$ tahun. Unsur $\mathrm{N}$ yang berada di dalam kompos diperkirakan sebesar $49.646 \mathrm{~kg} / \mathrm{tahun}$.

\subsection{Skenario 4}

Skenario 4 merupakan kombinasi aplikasi sistem desentralisasi komposting dengan sentralisasi komposting, yaitu melalui penerapan komposting skala rumah tangga dan skala kota. Dalam komposting skala kota, sampah yang diolah yaitu $36.115 .411 \mathrm{~kg} / \mathrm{tah} u n$. Sementara itu 
dalam komposting skala rumah tangga diolah $30 \%$ sampah dari perumahan atau sekitar $10.130 .089 \mathrm{~kg} /$ tahun.

Secara reguler, $70 \%$ sampah yang ditimbulkan oleh perumahan dan sampah yang ditimbulkan oleh sumber sampah lainnya dikumpulkan ke TPS. Dari TPS kemudian sampah diangkut dengan truk sampah ke plant komposting skala kota.

Dari hasil perhitungan didapatkan bahwa kebutuhan air untuk komposting skala kota adalah $5.334 .766 \mathrm{~kg} /$ tahun atau 5.335 ton/tahun. Sementara itu, produksi gas metana dari seluruh proses komposting skala kota adalah 7.255 $\mathrm{kg} /$ tahun. Tentang produksi komposnya, dari perhitungan didapat bahwa kompos yang dihasilkan sebanyak $8.798 .383 \mathrm{~kg} / \mathrm{tahun}$. Dari perhitungan diketahui pula bahwa jumlah recyclable materials diperkirakan mencapai $6.813 .037 \mathrm{~kg} / \mathrm{tahun}$. Sementara itu, jumlah residu diperkirakan sebanyak $3,374.217 \mathrm{~kg} / \mathrm{tahun}$.

Dari perhitungan komposting skala rumah tangga didapatkan bahwa produksi gas metana, kompos, recyclable materials dan residu dari seluruh proses komposting skala rumah tangga secara sama seperti yang dihasilkan dalam Skenario 2.

Dari perhitungan didapat bahwa unsur $\mathrm{N}$ yang yang diproduksi pada saat pengkomposan skala rumah tangga dan skala kota yaitu sebesar $85.788 \mathrm{~kg} /$ tahun dan $311.327 \mathrm{~kg} / \mathrm{tahun}$. Unsur N yang berada di dalam kompos yang diproduksi dalam skala rumah tangga dan skala kota diperkirakan sebesar $10.725 \mathrm{~kg} / \mathrm{tahun}$ dan $38.921 \mathrm{~kg} / \mathrm{tahun}$.

\subsection{Efektivitas Konsep Pengelolaan Sampah Organik Melalui Komposting}

Dalam kegiatan komposting baik Skenario 1, Skenario 2, Skenario 3, maupun Skenario 4 dengan input sampah sebesar 46.245 .500 $\mathrm{kg} / \mathrm{tahun}$ menghasilkan nilai output kompos, recyclable materials dan residu yang sama yaitu secara berturut-turut $111.222 .817 \mathrm{~kg} / \mathrm{tahun}$, $8.897 .809 \mathrm{~kg} / \mathrm{tahun}$ dan $4.274 .913 \mathrm{~kg} / \mathrm{tahun}$. Hal tersebut disebabkan karena baik komposting skala rumah tangga, skala lingkungan, maupun skala kota yang digunakan dalam skenarioskenario tersebut menggunakan teknologi yang pada prinsipnya sama yaitu proses aerobik yang diawali dengan proses pemilahan. Reduksi unsur $\mathrm{N}$ juga sama pada setiap skenario yaitu menjadi $397.115 \mathrm{~kg} / \mathrm{tahun}$. Sementara itu, konservasi unsur $\mathrm{N}$ di dalam kompos juga sama yaitu 49.646 $\mathrm{kg} /$ tahun. Perbedaannya terletak pada konsumsi air selama proses komposting yaitu pada desentralisasi komposting yang melibatkan komposting skala rumah tangga konsumsi airnya sebesar $5.334 .765 \mathrm{~kg} / \mathrm{tahun}$. Sedangkan pada sentralisasi komposting konsumsi airnya sebesar $6.804 .784 \mathrm{~kg} /$ tahun.

Sementara itu, dalam kegiatan komposting baik Skenario 1, Skenario 2, Skenario 3, maupun Skenario 4, nilai input $\mathrm{N}$ diperkirakan sebesar $871,728 \mathrm{~kg} / \mathrm{tahun}$. Unsur $\mathrm{N}$ yang berada dalam produk kompos diperkirakan $49.646 \mathrm{~kg} / \mathrm{tahun}$. Di dalam recyclable materials, unsur $\mathrm{N}$ tidak dianalisis karena keterbatasan data. Di dalam residu, unsur $\mathrm{N}$ juga tidak dianalisis karena keterbatasan data. Di dalam gas yang diemisikan dari proses komposting diperkirakan unsur $\mathrm{N}$-nya sebesar $397.115 \mathrm{~kg} / \mathrm{tahun}$.

Dalam penelitian sebelumnya, melalui analisis multikriteria, sebenarnya telah dipilih sistem yang paling tepat untuk diaplikasikan di Kota Probolinggo yaitu sistem desentralisasi komposting. Seperangkat kriteria yang digunakan untuk memilih opsi desentralisasi dan sentralisasi komposting terdiri atas 8 (delapan) kriteria yang di dalamnya meliputi 16 (enambelas) sub-kriteria. Dalam analisis efektivitas pengelolaan sampah organik ini, walaupun sistem sentralisasi bukan pilihan, sistem ini dijadikan sebagai salah satu skenario sebagai penyeimbang analisis.

Desentralisasi komposting dioperasikan secara manual dengan prinsip dekat dengan sumber sampah (proximity principle) dan berbasis masyarakat (community-based) ${ }^{(13)}$. Prinsip dekat dengan sumber artinya pengelolaan sampah dilakukan di area yang letaknya sedekat mungkin dengan sumber sampah, sedangkan prinsip berbasis masyarakat artinya masyarakat terlibat penuh dalam pelaksanaan pengelolaan sampah. Karakteristik teknis operasional desentralisasi komposting berbasis masyarakat antara lain adalah operasinya berskala kecil atau sedang, tingkat partisipasi masyarakatnya tinggi, dan inisiasinya dilakukan oleh masyarakat. Desentralisasi komposting berarti pula pendelegasian wewenang pengelolaan komposting dari instansi pengelola sampah kepada masyarakat atau unitunit pemerintahan terkecil seperti kelurahan atau desa. Dengan kewenangan itu masyarakat atau kelompok masyarakat berwenang mengatur dan mengurus kepentingannya sendiri menurut prakarsanya sendiri. 


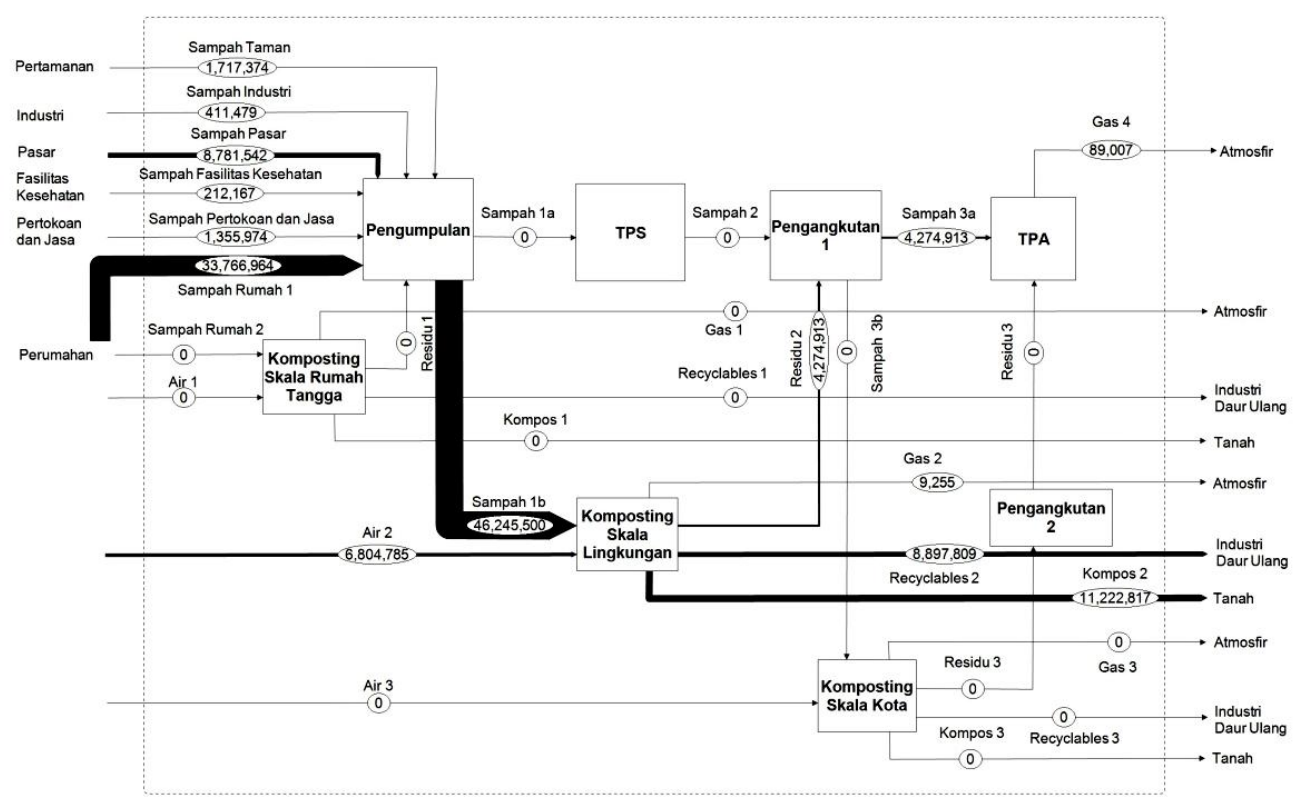

Gambar 2. Analisis aliran material skenario 1 (Seluruh angka dalam satuan kg/tahun)

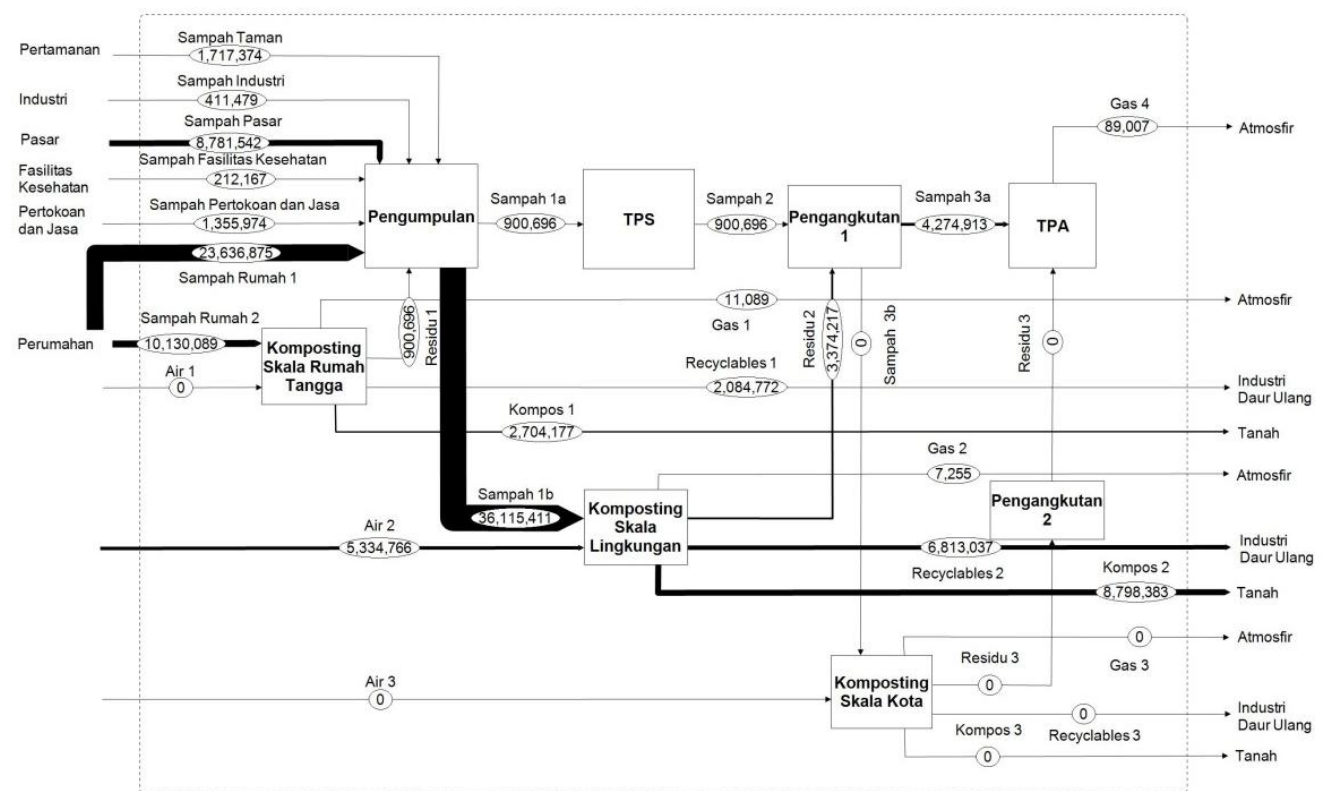

Gambar 3. Analisis aliran material skenario 2 (Seluruh angka dalam satuan kg/tahun)

Tabel 3. Input dan output material dari kegiatan desentralisasi dan sentralisasi komposting

\begin{tabular}{c|c|c|c|c|c|c}
\hline \multirow{2}{*}{ Skenario } & \multicolumn{2}{|c|}{ Input (kg/tahun) } & \multicolumn{4}{c}{ Output (kg/tahun) } \\
\cline { 2 - 7 } & Sampah & Air & Kompos & $\begin{array}{c}\text { Recyclable } \\
\text { materials }\end{array}$ & Residu & Gas $\mathrm{CH}_{4}$ \\
\hline Skenario 1 & 46.245 .500 & 6.804 .784 & 11.222 .817 & 8.897 .809 & 4.274 .913 & 9.254 \\
\hline Skenario 2 & 46.245 .500 & 5.334 .765 & 11.222 .817 & 8.897 .809 & 4.274 .913 & 18.344 \\
\hline Skenario 3 & 46.245 .500 & 6.804 .784 & 11.222 .817 & 8.897 .809 & 4.274 .913 & 9.254 \\
\hline Skenario 4 & 46.245 .500 & 5.334 .765 & 11.222 .817 & 8.897 .809 & 4.274 .913 & 18.344 \\
\hline
\end{tabular}

Desentralisasi komposting merupakan alternatif pengelolaan sampah yang efektif karena memiliki beberapa hal sebagai berikut:
1. Bersifat padat karya dan dapat beradaptasi secara baik pada kondisi sosio-ekonomi pemerintah daerah. 
2. Menciptakan lapangan kerja pada masyarakat urban yang berketerampilan terbatas.

3. Manajemen dan operasinya fleksibel sehingga secara cepat dapat beradaptasi dengan perubahan.

4. Menciptakan produk kompos yang dapat dipakai sebagai soil conditioner dan pupuk organik.

5. Mengurangi dampak lingkungan akibat lindi di TPA.

6. Mereduksi produksi gas rumah kaca terutama gas $\mathrm{CH}_{4}$.

\section{KESIMPULAN}

Tanpa adanya upaya pengolahan sampah, sampah akan terbuang dan tidak termanfaatkan. Padahal sampah adalah sumberdaya yang berguna. Komposting sampah kota memungkinkan material organik yang terkandung dalam sampah dikembalikan lagi ke tanah sehingga tingkat kesuburan tanah terjaga karena adanya tambahan material organik sebagai pengganti material yang terserap oleh tanaman yang dibudidayakan. Pengembalikan material organik ke alam berarti menjaga siklus alamiahnya. Proses pemilahan sampah yang dilakukan sebelum komposting akan menghasilkan recyclable materials seperti kertas, plastik, metal dan kaca. Material-material tersebut dapat digunakan kembali menjadi bahan baku industri sehingga dapat mengefisienkan penggunaan bahan baku yang dieksploitasi dari alam. Pengolahan sampah melalui komposting juga akan mereduksi gas $\mathrm{CH}_{4}$ yang berkontribusi dalam pemanasan global. Konsep pengelolaan sampah, terutama desentralisasi komposting merupakan alternatif pengelolaan sampah yang efektif karena bersifat padat karya; dapat beradaptasi secara baik pada kondisi sosioekonomi daerah; menciptakan lapangan kerja bagi masyarakat berketerampilan terbatas; dan manajemen serta operasinya fleksibel sehingga secara cepat dapat beradaptasi dengan perubahan.

\section{PERSANTUNAN}

Penulis mengucapkan terima kasih kepada rekan-rekan Pusat Teknologi Lingkungan dan Pemerintah Kota Probolinggo atas dukungan penelitiannya di Kota Probolinggo.

\section{DAFTAR PUSTAKA}

1. Wahyono, S., (2016), Desentralisasi Komposting: Mendorong Keberlanjutan Siklus Material Organik, Dalam Buku Rampai Kompos: Aplikasi di Lapangan., Ed., Sri Bebassari, BPPT Press.

2. Wahyono, S., (2015), Penyusunan Formula d Pemetaan Supply-Demand Kompos di
Wilayah Internal Perkotaan: Studi Kasus di Kota Probolinggo, Inovasi Teknologi Lingkungan untuk Pembangunan Berkelanjutan, Prosiding Pertemuan IImiah Nasional, BPPT Press.

3. Wahyono, S., S. Widanarko, S. Moersidik, dan S. Djajadiningrat, (2012), Metabolisme Pengelolaan Sampah Organik Melalui Teknologi Komposting Di Wilayah Internal Perkotaan: Kajian Pengelolaan Sampah Organik Pada Tipologi Kota Sedang Studi Kasus di Kota Probolinggo Jawa Timur, Jurnal Teknologi Lingkungan, Vol., 13, No., 2, Hal., 179-192

4. Anonim, (2006), IPCC Guidelines for National Greenhouse Gas Inventories, Volume 5 Waste, IPCC National Greenhouse Gas Inventories Programme, Jepang.

5. Morton, J., (2005), World Bank Experience in Landfill Gas and Prospects for Indonesia, Workshop on Landfill Gas for Energy Bali, Indonesia

6. Anonim, (2009), Indonesia's Technology Needs Assessment on Greenhouse Gasses Mitigation. GTZ

7. Anonim, (2010), Profil Persampahan Kota Probolinggo, Badan Lingkungan Hidup (BLH) Kota Probolinggo, Pemerintah Kota Probolinggo.

8. Anonim, (2006), Laporan Program Subsidi Kompos WJEMP, Kementerian Negara Lingkungan Hidup, Jakarta

9. Amlinger, F., (2008), Green House Gas Emissions from Composting and Mechanical Biological Treatment, Waste Manag Res, February 2008, 26: Hal., 47-60

10. Karthikeyan, O.P., dan K. Joseph, (2006), Anammox a Novel Process for Nitrogen Management in Bioreactor Landfills - a Review", Presented in National seminar on Integrated Municipal Solid Waste Management, Periyar Maniammai College of Technology for Women Thanjavur, Tamil Nadu.

11. Thchobanoglous, G., and F. Kreith, (2002), Handbook of Solid Waste Management, Mc Graw Hill, Inc., USA.

12. Andersen, J.K., (2010), Composting of Organic Waste: Quantification and Assessment of Greenhouse Gas Emissions, Department of Environmental Engineering Technical University of Denmark, Denmark.

13. Drescher, S., and C. Zurbrügg, (2006), Decentralised Composting: Lessons Learned And Future Potentials For Meeting The Millennium Development Goals CWG WASH Workshop 2006, 1 - 5 Februari di Kolkata, India. 